\title{
Beyond the urban stream syndrome: organic matter budget for diagnostics and restoration of an impaired urban river
}

\author{
Dave M. Epstein ${ }^{1}$ • Julia E. Kelso ${ }^{1} \cdot$ Michelle A. Baker $^{1}$ \\ Published online: 7 May 2016 \\ (C) The Author(s) 2016. This article is published with open access at Springerlink.com
}

\begin{abstract}
In response to water quality standard violations linked to excessive organic matter (OM) and a lack of sampling data informing the Total Maximum Daily Load (TMDL), an organic matter budget was created to quantify and identify sources of OM in the lower Jordan River (Salt Lake City, UT). By sampling dissolved, fine and coarse particulate OM, as well as measuring ecosystem metabolism at seven different sites, the researchers aimed to identify the origin of excess OM, and understand pathways by which different size classes of the OM pool are generated. The dissolved fraction (DOM; $94 \%$ ) was found to be the dominant form of OM transported within the river with fine particulate organic matter (FPOM; $6 \%$ ) the second most abundant, and coarse particulate organic matter (CPOM; $1 \%$ ) transport relatively insignificant in the overall $\mathrm{OM}$ budget. Primary production exceeded respiratory losses in the upper river, and this, along with $\mathrm{OM}$ inputs from two tributaries (where water reclamation facilities discharge into the river) delivered excess OM to the impaired lower reaches. Increasing stream metabolism index (SMI) with distance downstream ( $>1$ in the lower river) further demonstrated that transport of excessive organic matter into the lower river was from upstream sources and not due to lateral inputs. This simple approach to characterizing the organic matter budget as it relates to water quality in the Jordan River was effective and could serve as a model for future studies attempting to quantify and identify sources of OM in urban ecosystems.
\end{abstract}

A TMDL study defines the relationship between pollutant sources and in-stream water quality conditions. Based on this relationship, a permissible load is defined that will result in meeting state water quality standards and restore aquatic life beneficial use support for impaired segments of the river (UT DWQ 2012).

Electronic supplementary material The online version of this article (doi:10.1007/s11252-016-0557-x) contains supplementary material, which is available to authorized users.

Dave M. Epstein

davepstein@gmail.com

1 Department of Biology and the Ecology Center, Utah State University, 5305 Old Main Hill, Logan, UT 84322-5305, USA 
Keywords Water quality impairment · Organic matter budget · Urban stream syndrome

$\begin{array}{ll}\text { Abbreviations } \\ \text { AFDM } & \text { Ash-free dry mass } \\ \text { CPOM } & \text { Coarse particulate organic matter } \\ \text { DO } & \text { Dissolved oxygen } \\ \text { DOC } & \text { Dissolved organic carbon } \\ \text { ER } & \text { Ecosystem respiration } \\ \text { FPOM } & \text { Fine particulate organic matter } \\ \text { GPP } & \text { Gross primary productivity } \\ \text { HR } & \text { Heterotrophic respiration } \\ \text { OM } & \text { Organic matter } \\ \text { SMI } & \text { Stream metabolism index } \\ \text { TMDL } & \text { Total maximum daily load } \\ \text { FBOM } & \text { Fine benthic organic matter } \\ \text { LF } & \text { Litterfall } \\ \text { AR } & \text { Autotrophic respiration } \\ \text { LM } & \text { Lateral movement }\end{array}$

\section{Introduction}

Nowhere is the impact of human population growth and land alteration more apparent than in the water quality of urban rivers. In many cases this is a legacy effect of historic urban infrastructure that was designed to channel all runoff and wastewater directly into the closest river (Kaushal and Belt 2012) so that waste would be removed from the immediate area. Whether perennially via wastewater or ephemerally via storm water, a large amount of human-derived pollutants enters into rivers, resulting in unintended consequences such as eutrophication and reduced biotic richness (among others; e.g., Paul and Meyer 2001; Walsh et al. 2005; Wenger et al. 2009). Efforts to address water quality impairments in the United States are informed by the total maximum daily load (TMDL) process. In the case of eutrophication, such efforts often focus on controlling concentrations of nutrients (such as nitrogen and phosphorus) required for primary production of organic matter (OM). Indeed, in some cases it is the overabundance of OM that results in water quality issues associated with eutrophication (Wetzel 2001). Organic matter may also be directly deposited into streams and can contribute to depleted dissolved oxygen (DO) concentrations, thus threatening ecosystem health (Imberger et al. 2014). Investigating and controlling concentrations of both nutrients and OM should be considered when developing eutrophication mitigation strategies (e.g., Smith et al. 1999; Dodds 2007; Stanley et al. 2012).

Organic matter is often viewed as the currency of aquatic ecosystems (Lean et al. 1987), as it forms the base of the food web and directly influences ecosystem respiration and subsequently dissolved oxygen demand. Organic matter budgets provide insight into the relative importance of various energy resources (in-stream primary production, litterfall, upstream inputs, etc.) that support stream ecosystems and are a useful tool for evaluating and comparing different stream ecosystems (Odum 1968; Cummins et al. 1983; Webster and Meyer 1997; Tank et al. 2010). Multiple studies have created OM budgets in order to identify OM sources to consumers, evaluate the role of autotrophy in a given system, and to determine overall patterns by which OM inputs are used, altered and exported on an annual basis (Fisher and Likens 1973; Fisher 1977; Webster and Meyer 
1997; Young and Huryn 1997; Izagirre et al. 2008). The majority of these OM budgets were created for headwater streams in largely undisturbed watersheds and viewed OM as a limiting resource (Webster and Meyer 1997; Tank et al. 2010). In urban systems where novel aquatic ecosystems suffer from various symptoms of the urban stream syndrome (Walsh et al. 2005), DO concentrations are generally depleted and $\mathrm{OM}$ is abundant. As OM budgets are integrative measures of ecosystem condition, they may be useful in diagnosing symptoms of the urban stream syndrome. Metrics derived from OM budgets, in particular the stream metabolism index (SMI; Fisher 1977; which estimates the efficiency of respiration relative to input of organic matter to the system) as well as organic carbon turnover length $\left(\mathrm{S}_{\mathrm{OC}}\right.$; Newbold et al. 1982; which describes the downstream distance organic matter travels before it is respired) are useful in comparing ecosystem function among stream reaches (e.g.; Webster and Meyer 1997; Griffiths et al. 2012). In this study, these and other metrics of $\mathrm{OM}$ dynamics were explored in the context of an impaired urban river. The foundation of this research was based on answering the following questions: 1) Which size class of OM is dominant in the overall OM budget of the Jordan River and, 2) What is the source of OM responsible for depletion of DO concentrations in the lower river? These questions were motivated in part by water quality managers who hypothesized that CPOM from the urban forest was largely responsible for the water quality impairment in the lower river.

\section{Methods}

An organic matter budget was created for the Jordan River (Salt Lake City, Utah, USA) based on data collected during the 2012-2013 water year. The Jordan River exhibits the typical "symptoms" of an urban stream including a flashy hydrograph, elevated concentrations of nutrients and contaminants, increased diel DO fluctuations, homogenized channel morphology, and reduced biotic richness with the dominance of more tolerant species (Paul and Meyer 2001; Walsh et al. 2005; UT DWQ 2012). Further, late-summer DO concentrations in the lower river are often in violation of the defined minimum concentration suitable for aquatic organisms $\left(4.0-4.5 \mathrm{mg} \mathrm{L}^{-1}\right.$ depending on the time of year). The major goal of the study was to identify sources and sinks of the various pools of OM along the river, evaluate the balance between production and respiration at specific reaches, and to estimate and compare OM spiraling metrics to other rivers.

\section{Study area}

Located in the Great Salt Lake Basin of northern Utah (Fig. 1), the Jordan River is an 82-km regulated urban river that connects Utah Lake (40 $53^{\prime} \mathrm{N} 111^{\circ} 58^{\prime} \mathrm{W} ; 1368 \mathrm{~m}$ elevation) to the Great Salt Lake ( $40^{\circ} 21^{\prime} \mathrm{N} 111^{\circ} 53^{\prime} \mathrm{W} ; 1283 \mathrm{~m}$ elevation). The Jordan River Basin has a cold (avg. annual temp $12.7^{\circ} \mathrm{C}$ ) semi-arid climate with mean annual precipitation of $472 \mathrm{~mm}$, most of which occurs as snow (U.S. Climate Data 2015). The channel in the upper river is largely unshaded (width 16-32 m; Table 1), while the lower reaches have a more extensive and mature riparian corridor (width $\sim 16-39 \mathrm{~m}$; Table 1). The river is regulated by pumps at Utah Lake and flows north through four of Utah's six largest cities. The greater watershed (including Utah Lake; $9900 \mathrm{~km}^{2}$ ) is home to around 1.7 million people (1.6 million people in 2013; US Census Bureau 2015). Historically a cold-water fishery, the river is listed as impaired under Utah's 303(d) list (of impaired water bodies; U.S. code 1313(d)(1)(A)) in 7 of its 8 segments and no longer functions as a cold-water fishery. The river is extremely nutrient rich, where total nitrogen concentrations average $4.2 \mathrm{mg} \mathrm{L}^{-1}$ and total phosphorus concentrations average 
$0.7 \mathrm{mg} \mathrm{L}^{-1}$ (see Data Supplement). There are 6 major tributaries feeding into the river in addition to at least 8 water diversions removing water. One of these diversions, the Surplus Canal, diverts over half of river flow away from Salt Lake City for flood protection (Fig. 1). Four water reclamation facilities discharge directly into the Jordan River, two of which were encompassed within the study segment.

Seven sampling sites were established within the $35 \mathrm{~km}$ study segment between West Jordan and North Salt Lake City. These sites were named with the letters A through G, with site A located furthest upstream (river $\mathrm{km} \mathrm{40}$ ) and site $\mathrm{G}$ the furthest downstream site (river km 75; Fig. 1). The six study reaches (named \#'s 1 through 6) were between consecutive sample sites (mentioned previously), with site $\mathrm{G}$ serving as the downstream limit of reach \#6 and the greater study segment (Fig. 1). Site attributes changed predictably from site A downstream to site D as gradient, width, depth and discharge all increased (Vannote et al. 1980). However, the Surplus Canal diversion (along with channelization downstream of the diversion) disrupted this continuum, diverting over half of the flow out of the river. For the purposes of this analysis, from here on forward the Jordan River upstream of the Surplus Canal diversion will be referred to as the "upper river" (reaches \#1-3) and the portion below the diversion as the "lower river" (reaches \#4-6), given that the two river segments have distinct geomorphology and flow regimes.

\section{Organic matter transport}

A mass-balance approach similar to that used by Fisher and Likens (1973) was applied to the Jordan River, where the inputs of different size classes of OM into each river reach were compared to the export out of that particular reach. However, inputs and outputs such as throughfall DOM, insect emergence, and fish migration were not included as they were assumed to be minimal. Three OM size categories were sampled for analysis; 1) coarse particulate organic matter (CPOM), which consisted of organic fragments (excluding large branches/trees and garbage) greater than $1.0 \mathrm{~mm}$ mesh, 2) fine particulate organic matter (FPOM), OM greater than $0.7 \mu \mathrm{m}$ and smaller than $1 \mathrm{~mm}$, and 3) dissolved organic carbon (DOC) which served as a proxy for all OM smaller than $0.7 \mu \mathrm{m}$. Carbon content of CPOM and FPOM was measured using an elemental analyzer (see below).

Organic matter in transport was sampled every 1 to 4 weeks throughout the 2012-2013 water year (20 times total) at each of the seven sites. Transport measured at a given site was considered the "export" out of the reach immediately upstream and the "input" into the reach immediately downstream. Three replicate samples of CPOM, FPOM, and DOC were collected at each site during each sampling event. Fine particulate organic matter (FPOM) samples were collected by filtering river water with a handheld drill pump through $0.7 \mu \mathrm{m}$, glass-fiber filters (Whatman GF/F, Maidstone, United Kingdom) until clogged (see Kelso and Baker 2015). Filters were then transported back to the laboratory on ice, dried at $60{ }^{\circ} \mathrm{C}$ for $48 \mathrm{~h}$, weighed, combusted at $450{ }^{\circ} \mathrm{C}$, and weighed again to quantify ash-free dry mass (AFDM; Wallace et al. 2006) and elemental composition. Filtrate was transferred to glass vials and acidified to $\mathrm{pH} \sim 2$ with concentrated $\mathrm{HCl}$ prior to DOC analysis on a Shimadzu TOC-L analyzer via catalytic oxidation combustion at $720{ }^{\circ} \mathrm{C}$ (Shimadzu Corp., Kyoto, Japan). CPOM was sampled with bedload samplers based on the Helly Smith bedload sampler design. A mesh $(1 \mathrm{~mm})$ bag was attached to the back of the bedload sampler $\left(0.1 \mathrm{~m}^{2}\right)$ and a smaller net on a frame $\left(0.06 \mathrm{~m}^{2}\right)$ was attached to the top of the sampler handle and adjusted to the height of the water surface. Three bedload samplers were held perpendicular to the river flow near each bank and in the middle of the channel for 6 min and transport estimates were averaged among nets. Course particulate organic matter was picked from the nets and refrigerated before it was analyzed for AFDM and 


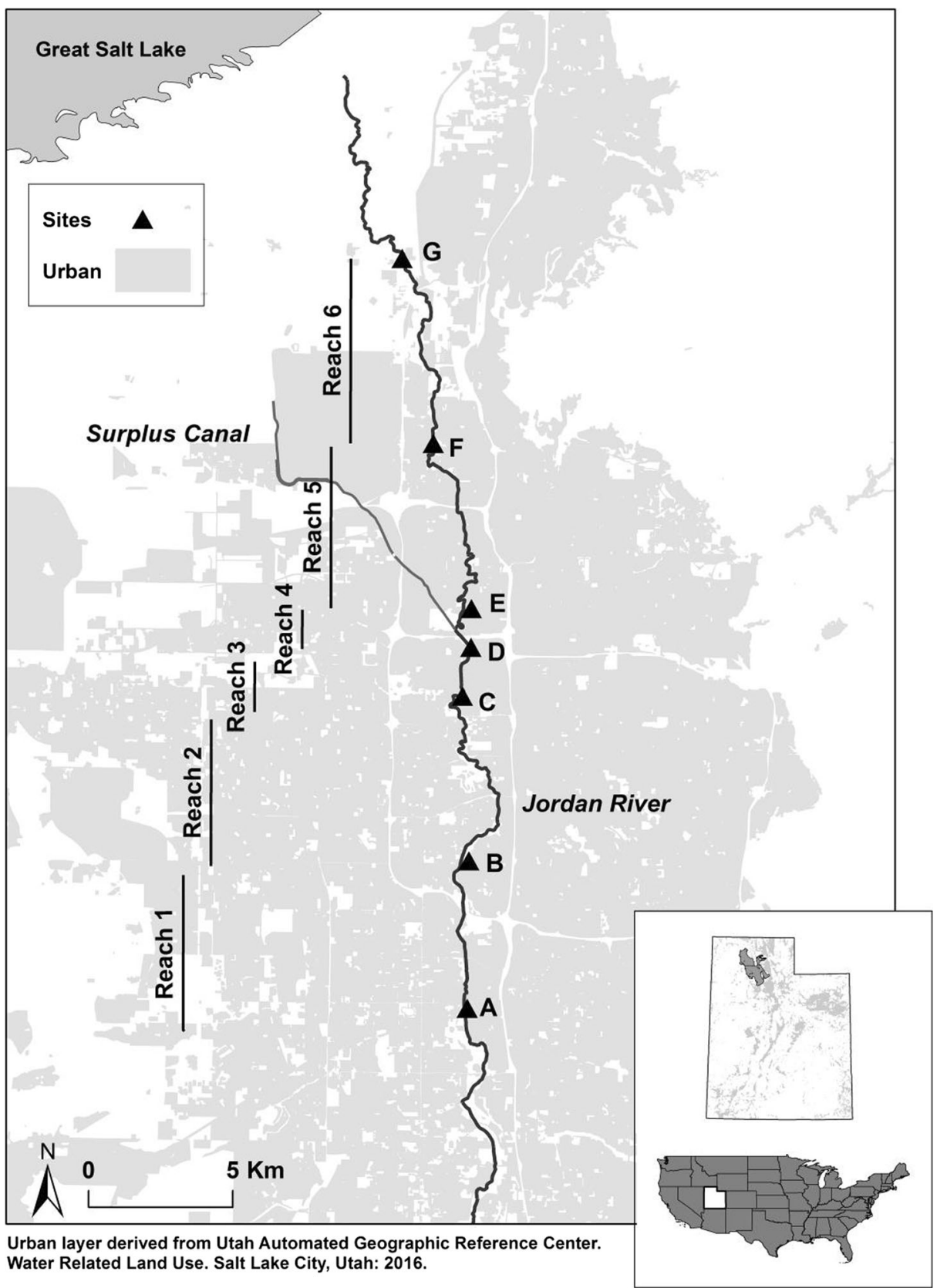

Fig. 1 The Jordan River (UT, USA) study area including the various study reaches (\#s 1-6) and sampling locations (A-G). The location of the Surplus Canal diversion is marked in the center of the figure, just between sites D and E. Publically owned treatment facilities discharge treated effluent into reaches \#1 (just downstream of Site A) and \#3 (just upstream of Site D). The developed urban areas of the watershed are depicted in light gray

elemental composition (as for FPOM, described above). A fixed volume of river water was filtered onto GF/F filters to obtain chlorophyll $a$ concentrations where filters were frozen prior to extraction in ethanol and analysis on a Turner handheld fluorometer (Turner Designs, 
Table 1 Reach characteristics and organic matter budget data for each of the six study reaches in the Jordan River study segment

\begin{tabular}{|c|c|c|c|c|c|c|}
\hline Reach \# & 1 & 2 & 3 & 4 & 5 & 6 \\
\hline Contributing Watershed Area $\left(\mathrm{km}^{2}\right)$ & 751 & 1087 & 1191 & 1243 & 1606 & 1683 \\
\hline Reach Area $\left(\mathrm{m}^{2}\right)$ & 94,590 & 170,886 & 57,085 & 54,743 & 121,836 & 140,580 \\
\hline Slope $(\%)$ & 0.16 & 0.09 & 0.001 & 0.03 & 0.03 & 0.02 \\
\hline Mean Annual Discharge $\left(\mathrm{m}^{3} \mathrm{~s}^{-1}\right)$ & 4.3 & 6.9 & 9.6 & 3.9 & 5.4 & 4.6 \\
\hline Mean Stream Width (m) & 16 & 20 & 32 & 39 & 16 & 17 \\
\hline Mean Depth (m) & 0.57 & 0.70 & 1.04 & 1.06 & 0.83 & 0.97 \\
\hline \multicolumn{7}{|l|}{ Inputs } \\
\hline $\operatorname{GPP}\left(\mathrm{g}_{-} \mathrm{Cm}^{-1} \mathrm{yr}^{-1}\right)$ & 3230 & 550 & 1750 & 1130 & NA & 400 \\
\hline Litterfall $\left(\mathrm{g}-\mathrm{Cm}^{-2} \mathrm{yr}^{-} 1\right)$ & 530 & 750 & 112 & 310 & 230 & 320 \\
\hline Lateral Movement (DOC; tonnes yr. ${ }^{-1)}$ & 586 & 543 & 1559 & -2021 & 458 & -403 \\
\hline Lateral Movement (FPOM; tonnes-C yr. ${ }^{-1)}$ & 45 & 44 & 80 & 128 & 19 & -12 \\
\hline \multicolumn{7}{|l|}{ Standing Crops } \\
\hline Dominant Substrates Type & Gravel & Gravel & Gravel/fines & Fines & Fines & Fines \\
\hline \multicolumn{7}{|l|}{ Outputs } \\
\hline $\mathrm{AR}\left(\mathrm{g}-\mathrm{C} \mathrm{m}^{2} \mathrm{yr}^{-1}\right)$ & 1420 & 250 & 770 & 500 & NA & 170 \\
\hline $\mathrm{HR}\left(\mathrm{g}-\mathrm{C} \mathrm{m}^{2} \mathrm{yr}^{-1}\right)$ & 960 & 640 & 1230 & 970 & NA & 630 \\
\hline DOC (tonnes yr. ${ }^{-1}$ ) & 1325 & 1868 & 3427 & 1406 & 1864 & 1461 \\
\hline FPOM (tonnes-C yr. ${ }^{-1}$ ) & 85 & 129 & 208 & 80 & 99 & 86 \\
\hline $\mathrm{CPOM}$ (tonnes-C $\mathrm{yr}^{-1}$ ) & 7 & 13 & 28 & 6 & 9 & 14 \\
\hline
\end{tabular}

Sunnyvale, CA). Extracted samples were acidified and reanalyzed for phaeophytin correction (Arar and Collins 1997).

River stage was monitored with capacitance water level loggers (Tru-Track, Inc., Christchurch, New Zealand) every $15 \mathrm{~min}$ and rating curves were developed using power regressions (MS Excel; Buchanan and Somers 1976) using 15 discharge measurements collected during sampling trips across the full range of flows. Discharge was measured from bridges across the Jordan River by traversing a StreamPro Acoustic Doppler Current Profiler boat (ADCP; Teledyne RD, Poway, $\mathrm{CA}$ ) from one bank to the other and taking the average of four discharge measurements that differed by less than $5 \%$. For a given sampling event, measured concentrations of each OM pool were multiplied by discharge to generate estimates of OM transport. These gross estimates were divided by the contributing watershed area at each site to estimate OM yields.

To estimate riparian litter inputs, 5 litterfall baskets $\left(0.24 \mathrm{~m}^{2}\right)$ were placed in the riparian zone (outside the channel) near each sampling location in September 2012. Litter inputs were collected periodically until leaf fall ended in December 2012. Samples were oven dried and AFDM was estimated using the previously described method. CPOM input as leaf litter was estimated with the assumption that one third of total litterfall (averaged from 5 replicates per segment) entered directly into the stream channel (Fisher 1977).

\section{Ecosystem metabolism}

Dissolved oxygen concentrations and temperature were measured at the 7 sample sites every 10 min for 10 to 20 -day durations with water quality sondes (YSI, Yellow Springs, OH) during 
the months of October (2012), and February, March and July (2013). Metabolism was calculated using the single-station method at the 7 different sampling locations and modeled using the following equation (Van de Bogert et al. 2007):

$$
\frac{d O}{d t}=G P P-E R+D
$$

where the rate of change of dissolved oxygen $(\mathrm{dO} / \mathrm{dt})$ is equal to the difference in gross primary production (GPP) and ecosystem respiration (ER), plus exchange of oxygen with the atmosphere (D). The variable D represents gas exchange as the product of $\mathrm{O}_{2}$ transfer velocity $(k)$ and the difference in river $\mathrm{O}_{2}$ concentration relative to $\mathrm{O}_{2}$ saturation. Thus $\mathrm{D}$ is represented by:

$$
D_{t}=\frac{k\left(\mathrm{O}_{2 s a t}-O_{t}\right.}{z}
$$

where $D_{t}$ is the diffusion at time t, $k$ is the reaeration coefficient, $O_{t}$ is the river oxygen concentration at time $t$, and $z$ is mean river depth (Van de Bogert et al. 2007).

Probability distributions of GPP, ER, $\mathrm{D}_{\mathrm{t}}$, and photosynthesis-irradiance relationships were modeled based on measured $\mathrm{O}_{2}$ concentrations, water temperature, and irradiance at each site. Dissolved oxygen was modeled in response to changing light intensity and temperature to simultaneously estimate metabolism and reaeration (Van de Bogert et al. 2007; Holtgrieve et al. 2010).

$$
y_{t+1}=y_{t}+G G P\left(\frac{P A R_{t}}{P A R 24}\right)-\mathrm{ER} \Delta \mathrm{t}+D_{t} \Delta+z_{t}
$$

The model is based on the Bayesian Metabolic Model developed by Holtgrieve et al. (2010). Thus when light it not saturating, GPP is a linear function of irradiance modeled as:

$$
P(I)=\alpha_{P-I}(I)
$$

where $\alpha_{P_{-} I}$ is the slope of the photosynthesis-irradiance line at low light levels. Respiration is modeled as a temperature-dependent process based on the van't Hoff-Arrhenius equation:

$$
R(T)=R_{20} 1.04^{(T-20)}
$$

where $T\left({ }^{\circ} \mathrm{C}\right)$ is water temperature and $\mathrm{R}_{20}$ is respiration at $20{ }^{\circ} \mathrm{C}$ (Venkiteswaran et al. 2008; Holtgrieve et al. 2010). Solar radiation data were downloaded from University of Utah's Mesowest website (mesowest.utah.edu). Autotrophic respiration was estimated as $45 \%$ of GPP (Hall and Beaulieu 2013) and heterotrophic respiration was back-calculated from total (ecosystem) respiration. Modeling of ecosystem metabolism was done in R (R Development Core Team 2016; www.r-project.org). Metabolism estimates were converted from oxygen to carbon units with molar ratios.

\section{Benthic organic matter standing stocks}

Standing stock of benthic OM was estimated quarterly in each of the six study reaches. Each reach was sampled by canoe, where benthic substrate composition was estimated along with water depth (and macrophyte coverage) from a minimum of 10 locations along at least 5 transects (in each reach) using a graduated pole to measure depth and to probe substrate type 
(modified from Bowden et al. 2006). Wetted width was measured using a laser range finder (Bushnell Pro Sport 450, $\pm 1 \mathrm{~m}$ accuracy) at $\sim 25$ locations within each segment. Samples of each substrate type (cobble, gravel, wood, and fine sediment) were collected at five different locations within each reach. Organic matter was removed from cobble and wood substrates and rinsed into a known volume of water, which was filtered and collected onto pre-ashed GF/F filters and analyzed for both AFDM and Chl $a$. The surface areas of cobble and wood substrates were estimated from digital images using ImageJ (Abramoff et al. 2004) to digitally trace substrate areas relative to a known distance reference (ruler) in each image. The top $3 \mathrm{~cm}$ of gravel and fine sediments was collected using a $4.6 \mathrm{~cm}$ diameter PVC coring device and stored in sample cups. Samples were then sonicated with a known volume of water and fine materials were filtered onto ashed GF/F filters as described above. Total organic matter standing stocks were scaled to the particular reach using estimates of reach area and percent distribution of the benthic substrates in each segment.

\section{Stable isotope signatures of $\mathrm{OM}$}

Potential sources of particulate OM including periphyton, macrophytes, riparian vegetation, and senesced leaf litter were collected for isotopic analysis to identify isotopic end members for a mixing model. A subset of $84 \mathrm{CPOM}$ samples was selected from the months of May, July, October and February for $\delta^{13} \mathrm{C}$ and $\delta^{15} \mathrm{~N}$ isotope analyses. Additionally, a subset of 48 FPOM samples from July and October at each site was fumigated with $\mathrm{HCl}$ to remove inorganic carbon (Harris et al. 2001) and analyzed for $\delta^{13} \mathrm{C}$ and $\delta^{15} \mathrm{~N}$ isotopes. Samples were encapsulated and sent to the University of California at Davis Stable Isotope Facility and analyzed on a PDZ Europa ANCA-GSL elemental analyzer interfaced to a PDZ Europa 20-20 isotope ratio mass spectrometer (Sercon Ltd., Cheshire, UK). The isotopic composition $(\delta)$ of samples was calculated as:

$$
\delta \mathrm{X}=\left[\left(R_{\mathrm{SAMPLE}} / P_{\mathrm{STANDARD}}-1\right)\right] * 1000
$$

where $\mathrm{R}$ is the ratio of fractional abundance of heavy to light isotopes for element X (Fry 2006).

The Stable Isotope Analysis in R (SIAR) package provides a Bayesian inference mixing model designed to estimate the proportional contribution of sources to a mixture (Parnell et al. 2010). The advantages of SIAR include the ability to incorporate and report variability in source, end member, as well as the inclusion of an overall residual error term (Parnell et al. 2010). The model was used to identify the relative contributions of autochthonous (macrophytes and biofilms) and terrestrial (leaf litter and riparian tree leaves and grasses) sources for FPOM and CPOM.

\section{Organic matter budget calculations and metrics}

Organic matter fractions measured as AFDM were converted to organic carbon units from the proportion of carbon in samples measured as part of stable isotope analysis (above). Direct measurements of CPOM $(33 \% \mathrm{C}), \operatorname{FPOM}(11 \% \mathrm{C})$, and DOC concentrations were applied to half of the days between previous and subsequent sampling events to generate daily transport estimates based on discharge data from rating curves. This interpolation method may have underestimated transport for all three constituents. These estimates were summed to generate 
gross annual export of organic carbon $\left(\mathrm{kg}-\mathrm{C} \mathrm{yr}^{-1}\right)$ at each sample location. Transport yield ( $\mathrm{kg}-\mathrm{C} \mathrm{km}{ }^{-2} \mathrm{yr}^{-1}$ ) was estimated by dividing gross transport estimates by the contributing watershed area to the given sampling location.

Spiraling metrics were calculated to characterize carbon dynamics within the river (e.g. Webster and Meyer 1997). Carbon mineralization velocity (analogous to uptake velocity; $\mathrm{m} \mathrm{d}^{-1}$ ) was calculated using an equation from Hall et al. (2015):

$$
\mathrm{V}_{\mathrm{f}-\mathrm{OC}}=-\mathrm{HR} /[\mathrm{OC}]
$$

where HR is heterotrophic respiration $\left(\mathrm{g}-\mathrm{C} \mathrm{m}^{-2} \mathrm{~d}^{-1}\right)$ and [OC] is the concentration of organic carbon in the stream $\left(\mathrm{g} \mathrm{m}^{-3}\right)$. Spiraling length $\left(\mathrm{S}_{\mathrm{OC}}, \mathrm{m}\right)$ was calculated following the equation from Hall et al. (2015):

$$
\mathrm{S}_{\mathrm{OC}}=(\mathrm{Q} *[\mathrm{OC}]) /\left(-\mathrm{HR}^{*} w\right)
$$

where $\mathrm{Q}$ is the discharge of the Jordan River $\left(\mathrm{m}^{3} \mathrm{~s}^{-1}\right)$, [OC] is the total concentration of organic carbon in the stream $\left(\mathrm{g} \mathrm{m}^{-3}\right)$, HR is heterotrophic respiration $\left(\mathrm{g}-\mathrm{C} \mathrm{m}^{-2} \mathrm{~d}^{-1}\right)$ and $w$ is the width of the stream (m). As initially proposed by Fisher (1977) and later by others (Cummins et al. 1983; Newbold et al. 1982; Webster and Meyer 1997), stream metabolism index (SMI) was calculated as the ratio of observed respiration to respiration needed to prevent accumulation of organic matter:

$$
\mathrm{SMI}=\mathrm{R}_{\mathrm{E}} /(\mathrm{GPP}+\mathrm{LF}+\mathrm{LM})
$$

where $\mathrm{R}_{\mathrm{E}}$ is ecosystem respiration, GPP is the gross primary production in the reach, LF is litterfall and LM is lateral movement (FPOM and DOM inputs to the reach, either from tributaries, or point sources; all in $\mathrm{g}-\mathrm{C} \mathrm{m}^{-2} \mathrm{~d}^{-1}$ ). Lateral movement of CPOM was not included in these estimates due to their insignificance in influencing the result. Stream metabolism index values below 1 indicate net accumulation of OM due to upstream inputs as observed respiration is less than respiration necessary to prevent accumulation of OM inputs within the reach.

\section{Results}

\section{Organic matter transport and standing stocks}

Changes in $\mathrm{OM}$ transport between reaches in the study area were largely influenced by changes in discharge due to tributary inputs and/or water diversions. Discharge followed a predictable seasonal trend with the highest flows occurring during spring runoff; however, storm events in July and September resulted in late peaks in the hydrograph (Fig. 2). Discharge increased incrementally with distance downstream from the furthest upstream site (site A) down to site $\mathrm{D}$, which conveyed the highest discharge of the seven sample locations consistently throughout the year (Table 1, Reach \#3). However, as discharge increased predictably with distance downstream, the continuum of the Jordan River was disrupted just downstream of site D where the Surplus Canal diverts the majority of the river's flow around Salt Lake City. Therefore, discharge at site E was on average less than half of the discharge at site D, even though the two sites are only about $1.5 \mathrm{~km}$ apart (Fig. 1). Flows through the lower river were maintained at a relatively stable level throughout the study period due to the Surplus Canal diversion, which diverts over half of river's flow away from Salt Lake City for flood protection (Fig. 1). 
Fig. 2 Average daily discharge values $\left(\mathrm{m}^{3} \mathrm{~s}^{-1}\right)$ for three of the sampling sites (A, D and G) along the Jordan River. Star symbols along the $\mathrm{x}$-axis indicate the dates when discharge measurements were made and samples were taken

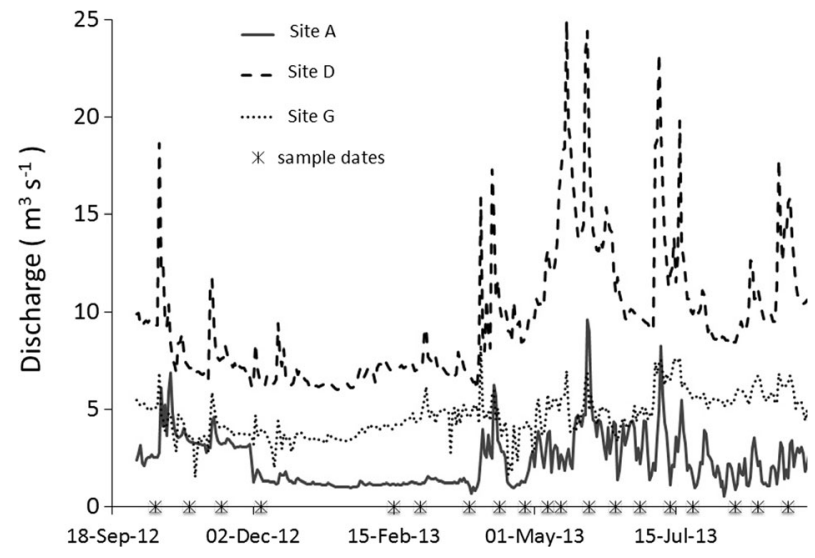

Throughout the 2012-2013 water year the overall OM budget was dominated by the dissolved fraction at all seven sites, where DOC transport $\left(737,916-3427,084 \mathrm{~kg} \mathrm{C} \mathrm{yr}^{-1}\right)$ was on average an order of magnitude greater than FPOM transport (39,845-208,425 $\left.\mathrm{kg} \mathrm{C} \mathrm{yr}^{-1}\right)$ and two orders of magnitude greater than CPOM transport (6023-27,514 $\mathrm{kg} \mathrm{C} \mathrm{yr}^{-1}$; data shown in Data Supplement). Dissolved organic carbon transport was greatest in fall months while FPOM transport was greatest in spring and summer months (Fig. 3). The average variation among replicates on a given date at all sites was low for DOC (CV 8.6 \%) and FPOM (CV $11.5 \%$ ) but high for CPOM (CV $80 \%$ ). The standard deviations of annual OM transport estimates based on individual samples at each site were small $(<2.5 \%$ DOC, $<1.5 \%$ FPOM, $<0.5 \%$ CPOM) for all OM pools.

The transport of OM through our study segment of the Jordan River showed an accumulating trend with distance downstream (Figs. 4 and 5 each show a representative picture of the OM budget for upper (Fig. 4) and lower river (Fig. 5) sites). For both DOC and FPOM, transport increased incrementally from site A (furthest upstream) to a maximum at site D (Fig. 6). Downstream of site D, gross OM transport through the river was reduced due to the Surplus Canal diversion and was comparable in magnitude to sites $\mathrm{B}$ and $\mathrm{C}$ in the upper river. The greatest increases in OM transport were found within reaches $\# 1$ and $\# 3$, indicating

Fig. 3 Average (of all sites sampled) monthly organic matter transport yield $(\mathrm{kg}-\mathrm{C}$

$\mathrm{km}^{-2}$ month ${ }^{-1}$ ) through the Jordan River. Coarse particulate organic matter is shown in black (hardly visible at the top of each column), fine particulate organic matter in white and dissolved organic carbon in gray

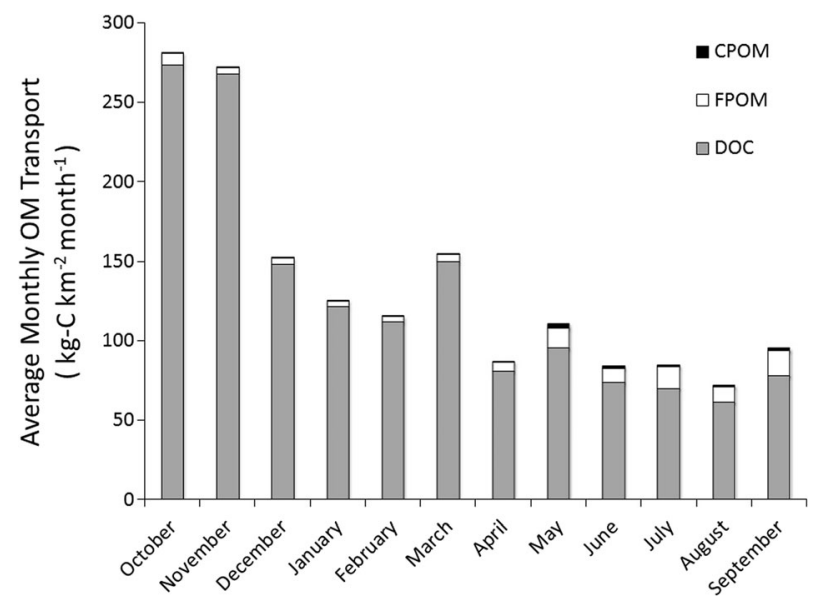




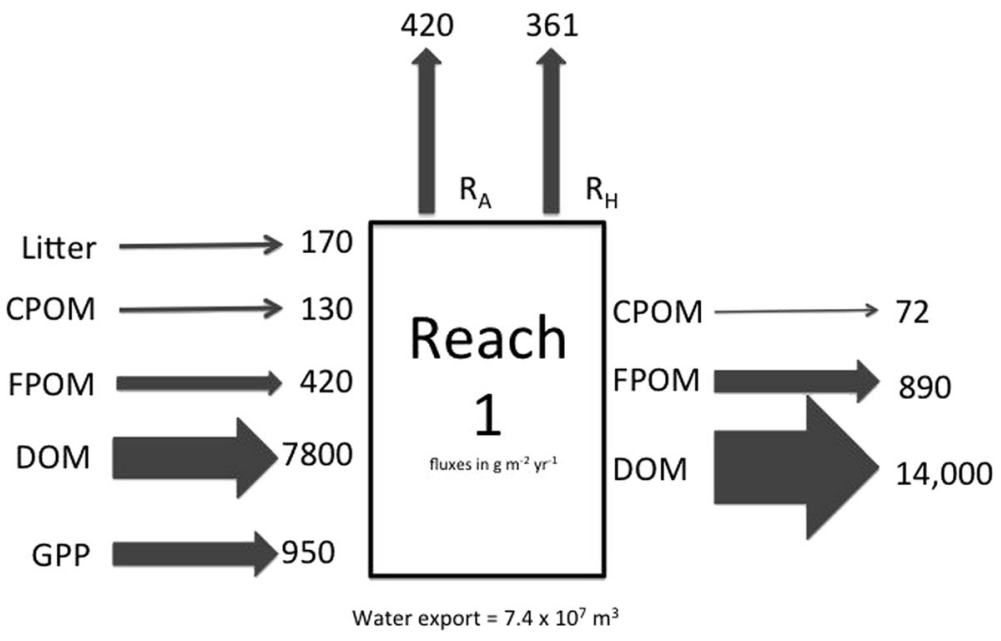

Upper Jordan River, after Benstead et al. 2009

Fig. 4 The overall organic matter budget for the upper Jordan River (at reach 1). Inflows of OM into the reach are shown on the left of the diagram (arrows pointing towards the box) and outflows are shown above and to the right of the figure (arrows leaving the box). The width of each arrow indicates the magnitude of the given OM flux. Inputs and outputs (arrows) are in grams of carbon per square meter per year

significant tributary inputs within those reaches (Fig. 6). Given that a portion of the OM accumulation appeared to be driven by increasing discharge, OM transport "yield" was evaluated by dividing gross transport by contributing watershed area for each site. Yield analysis further identified reaches $\# 1$ and $\# 3$ as "gaining reaches" (Fig. 6b), contributing disproportionally to overall OM transport within the river. However, losses of OM were

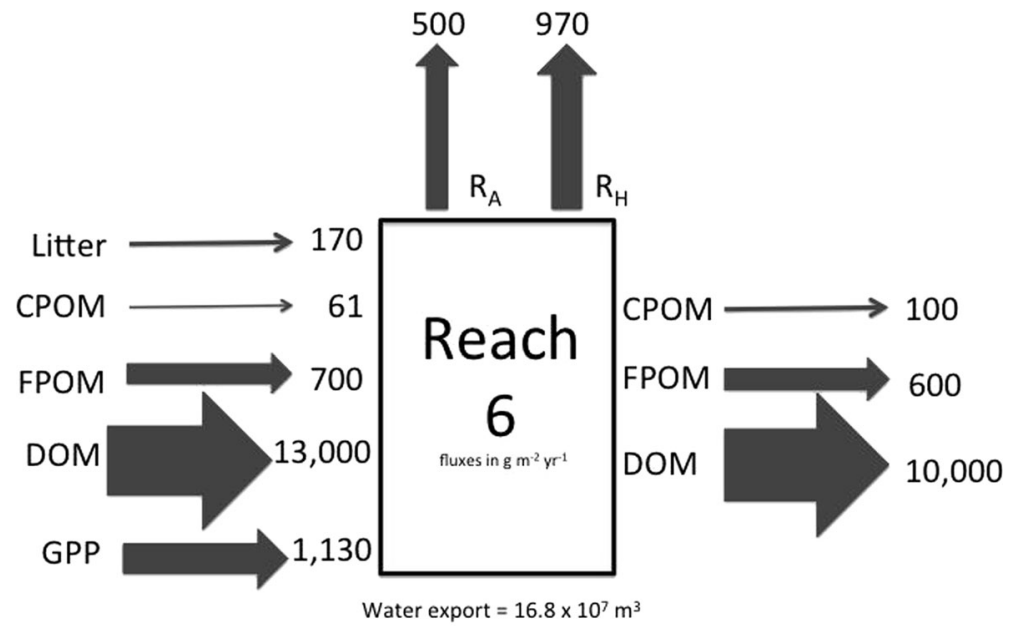

Lower Jordan River, after Benstead et al. 2009

Fig. 5 The overall organic matter budget for the lower Jordan River (reach 6). Inflows of OM into the reach are shown on the left of the diagram (arrows pointing towards the box) and outflows are shown above and to the right of the figure (arrows leaving the box). The width of each arrow indicates the magnitude of the given OM flux. Inputs and outputs (arrows) are in grams of carbon per square meter per year 

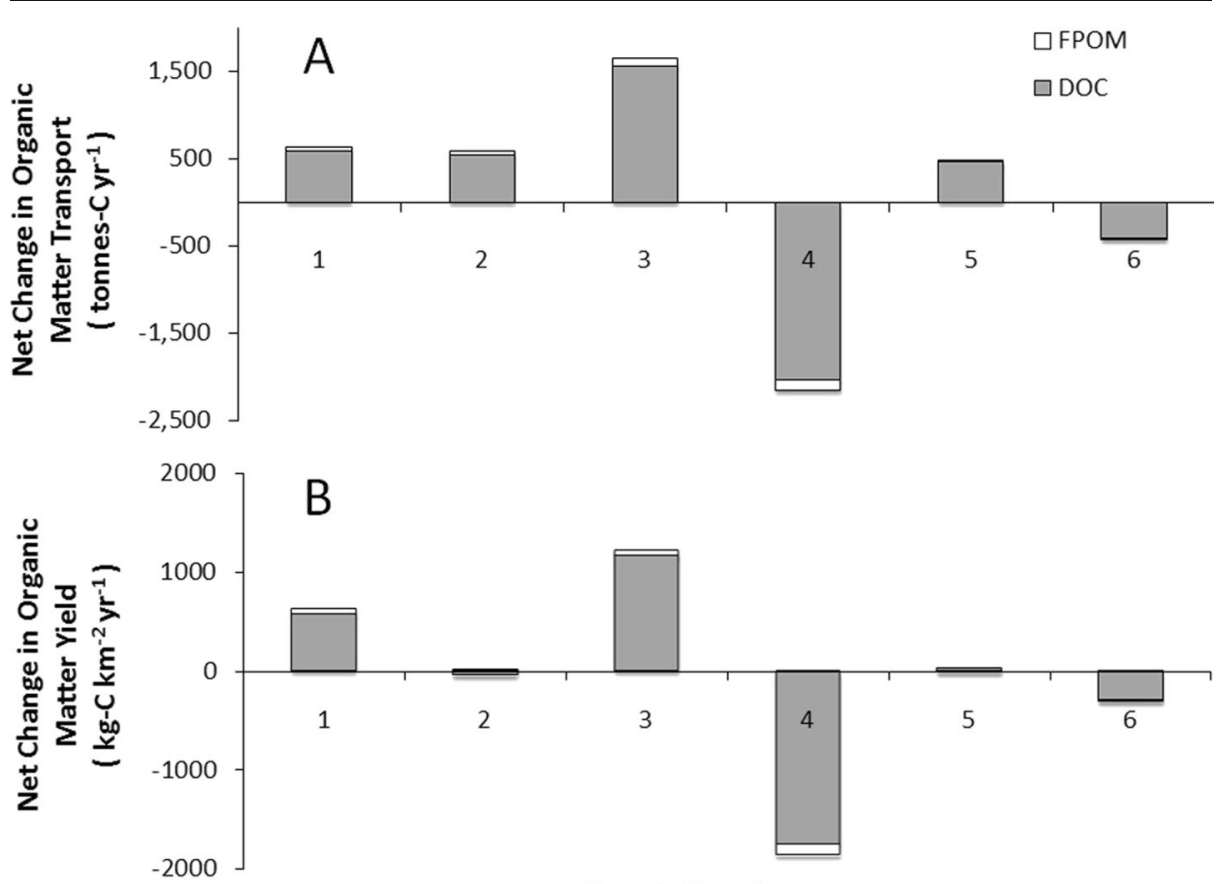

Reach Number

Fig. 6 Estimates of the net change in organic matter transport within each of the six sampling reaches. The changes in CPOM transport from one sampling location to the next were so low relative to those for DOC that they were omitted from the figure

observed in several reaches, notably a loss of DOC in reaches \#2 (3\%), \#4 (61\%) and \#6 ( $25 \%$; Fig. 6). Water chemistry dynamics (nutrients) largely followed the same trends as DOC and FPOM, with significant gains in TN, TP, nitrate, ammonium and SRP in reaches \#1 and \#3 (see Data Supplement).

The transport of CPOM downstream through the study segment did not follow a clear trend, due to variability in riparian vegetation density (litterfall estimates and field surveys) and in-stream CPOM measurements. While CPOM transport was greatest at site D, transport did not increase in the same downstream progression as DOC and FPOM transport. There was, however, a fairly clear change in the composition of CPOM from the upper to the lower river sites. Within the two furthest upstream reaches (\#1 and \#2) there was a dominance of filamentous algae in CPOM samples, particularly during the early spring. Long brown-green filaments were captured from the water column, which accumulated into conglomerates in the sample nets. This contrasted dramatically with the dominance of allochthonous plant material in CPOM samples from the lower river, including flowers, seeds, sticks, and leaves.

Litterfall estimates at the 7 sample locations were variable in time, space, and composition. Samples mainly included leaves (cottonwood, tamarisk, willow, reed canary grass, etc.), branches and seeds, but not all litterfall sample types were found at all sample locations. Litterfall estimates ranged from $47 \mathrm{~g}-\mathrm{C} \mathrm{m}^{-2} \mathrm{yr}^{-1}$ (AFDM) at site D to $224 \mathrm{~g}-\mathrm{C} \mathrm{m}^{-2} \mathrm{yr}^{-1}$ at site B. Estimates for total litterfall in each of the sites for the entire autumn of 2012 were on average $1418 \mathrm{~kg}-\mathrm{C}$ and ranged from $184 \mathrm{~kg}-\mathrm{C}$ at site D to $3251 \mathrm{~kg}-\mathrm{C}$ at site $\mathrm{B}$. Litterfall may 
have contributed as much as $48 \%$ of the CPOM transport at some sites; however, CPOM did not make up more than $1 \%$ of total OM transport through the river.

Chlorophyll $a(\mathrm{Chl} a)$ concentrations were much greater in the upper river than the lower river but on average $\mathrm{Chl} a$ was only a small proportion ( $\sim 2 \%)$ of total FPOM. Concentrations of Chl $a$ were greatest at site B $\left(\sim 20 \mu \mathrm{g} \mathrm{L}^{-1}\right)$, where conglomerates of filamentous algae were clearly visible within the water column, and decreased into the lower river (sites $\mathrm{F}$ and $\mathrm{G}$; $\sim 5 \mu \mathrm{g} \mathrm{L}^{-1}$ ). The ratio of FPOM to Chl $a$ in the water column increased with distance downstream and dramatically from site $\mathrm{C}$ to $\mathrm{F}$, demonstrating a reduction in the proportion of Chl $a$ in the water column in the lower river.

The composition of benthic substrate changed dramatically from reach \#1 downstream to reach \#6; from mostly cobble and rock to fine sediments (Table 1). These small-particle sediments contained a greater concentration of OM than other substrate types and therefore benthic OM was found to increase with distance downstream. The estimated OM standing stock in reach \#6 (furthest downstream) was by far the greatest of all the sample reaches (see Data Supplement).

\section{DO and metabolism}

Metabolism estimates generated from dissolved oxygen and temperature measurements indicated largely autotrophic conditions in the upper river and increasing heterotrophy in the lower river (Fig. 7). Diel DO variation was high at the uppermost sites (4 $\mathrm{mg} \mathrm{L}^{-1}$ diel range) and low (1 $\mathrm{mg} \mathrm{L}^{-1}$ diel range) in the lower river (particularly site $\left.\mathrm{G}\right)$. Estimates of reaeration $\left(\mathrm{K} ; 0.4-17 \mathrm{~d}^{-1}\right)$ varied both seasonally and between sites but overall a reduction in channel slope with distance downstream coincided with lower reaeration values in the lower river. Modeled gross primary production (GPP) ranged from 1 to $13 \mathrm{~g}-\mathrm{C} \mathrm{m}^{-2} \mathrm{~d}^{-1}$ while modeled ecosystem respiration (ER) ranged from -12 to $-1 \mathrm{~g}-\mathrm{C} \mathrm{m}^{-2} \mathrm{~d}^{-1}$. Mineralization velocity (analogous to uptake velocity, $\mathrm{v}_{\mathrm{f}}$ ) estimates ranged from 0.14 to $0.44 \mathrm{~m} \mathrm{~d}^{-1}$ and spiraling lengths ranged from 73 to $169 \mathrm{~km}$, much longer than the length of the study segment $(35 \mathrm{~km})$. Stream metabolism index (SMI) estimates for reaches in the upper river ranged from 0.16 to 0.38 but were greater in the lower river (1.0 to 1.1$)$.

\section{Isotopes}

Stable isotope analyses of autochthonous and terrestrial sources of OM elucidated the origin of FPOM and CPOM transported within the Jordan River (Fig. 8). The SIAR model found CPOM samples $(n=185)$ were primarily composed of terrestrial sources (mean $=80 \%$, range 72 to $84 \%)$ and FPOM samples $(n=48)$ were found to be a mixture of autochthonous (mean $=80 \%$, range 50 to $98 \%$ ) and terrestrial sources (mean $=20 \%$, range 10 to $50 \%$ ). Autochthonous sources of OM (biofilms and macrophytes) had $\delta^{13} \mathrm{C}$ isotope values of $-22.3 \pm 1.6 \%$ and $-23.6 \pm 2.6 \%$, respectively, and $\delta^{15} \mathrm{~N}$ isotope values of $12.0 \pm 3.7 \%$ o and $14.2 \pm 6.0 \%$ (see Data Supplement). Terrestrial sources (senesced and fresh) had $\delta^{13} \mathrm{C}$ isotope values of $-27.7 \pm 0.6 \%$ and $-28.2 \pm 1.9 \%$, and $\delta^{15} \mathrm{~N}$ isotope values of $3.9 \pm 3.0 \%$ and $6.2 \pm 4.8 \%$. Autochthonous sources had much lower molar C:N values (biofilms, $7.9 \pm 1.3$, macrophytes, $12.2 \pm 1.1$ ) than terrestrial sources (senesced, $41.5 \pm 7.0$, fresh, $21.6 \pm 16.2$; see Data Supplement). Coarse particulate organic matter $\delta^{13} \mathrm{C}$ isotope values were more similar to terrestrial $\delta^{13} \mathrm{C}$ isotope values while FPOM $\delta^{13} \mathrm{C}$ isotope values were more similar to autochthonous sources (Fig. 8). Nitrogen isotope values were much more 
Fig. 7 Average net ecosystem metabolism estimates $\left(\mathrm{g}-\mathrm{C} \mathrm{m}{ }^{-2}\right.$ $\mathrm{d}^{-1}$ ) for six sampling locations along the study segment of the Jordan River (measured data at site F (km 66) were not usable). Positive metabolism estimates indicate autotrophy with production greater than respiration, while negative values indicate heterotrophy with production less than respiration

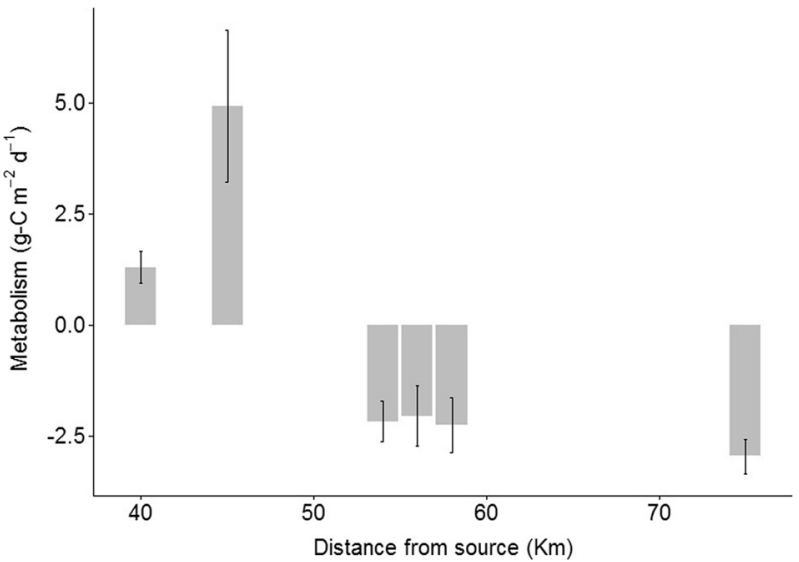

variable than carbon isotope values and did not differentiate CPOM and FPOM organic matter as well as carbon isotope values. However, molar $\mathrm{C}: \mathrm{N}$ values indicated that CPOM was more similar to terrestrial sources, while FPOM was more similar to autochthonous sources.

\section{Discussion}

The urbanization of landscapes causes substantial alterations to watershed processes and subsequent stream function. Elevated OM loads throughout the Jordan River are attributed to urbanization of the watershed and the discharge of pollutants directly into the river. As previously described, the Jordan River suffers from symptoms of the urban stream syndrome, which can be traced back to the initial development of Salt Lake City and the greater Jordan River watershed. Some of the many factors impacting the Jordan River are agricultural runoff draining into Utah Lake (Jordan River source water), direct stormwater and reclaimed water inputs to the Jordan River, and regulation of the flow regime out of Utah Lake and by the Surplus Canal diversion. Flows out of Utah Lake are regulated in an attempt to

Fig. 8 Stable isotope ratios $\left(\delta^{13} \mathrm{C}\right.$ and $\left.\delta^{15} \mathrm{~N}\right)$ for organic matter $(\mathrm{OM})$ sources within the Jordan River. The OM "sources" are depicted by dark symbols (filled-in black) while FBOM, CPOM and FPOM pools are depicted by open symbols (not filled-in). Individual points are samples taken from October 2012 to September 2013 and $\delta{ }^{13} \mathrm{C}$ is shown on the $\mathrm{x}$-axis while $\delta^{15} \mathrm{~N}$ is shown on the y-axis

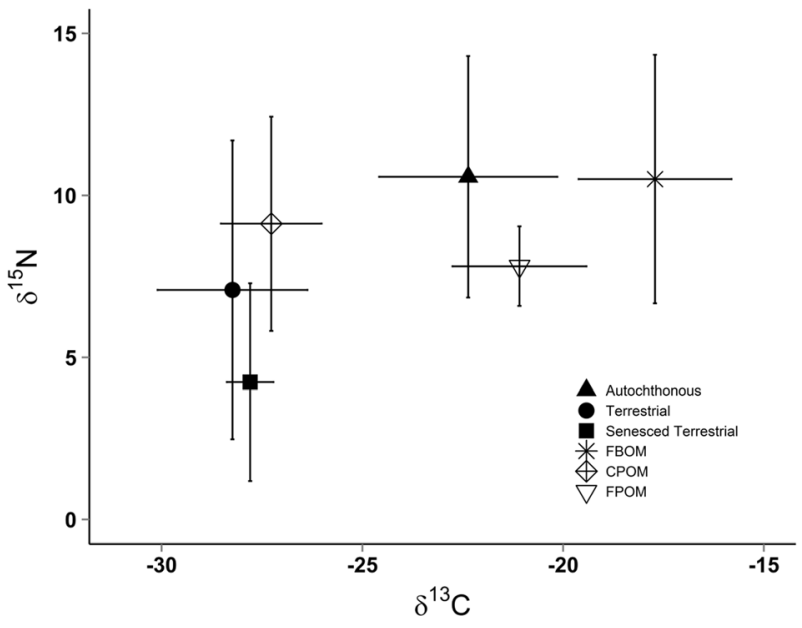


prevent flooding and thus rarely exceed $5.7 \mathrm{~m}^{3} \mathrm{~s}^{-13}$. Additionally, over half of river discharge is diverted by the surplus canal resulting in artificially low flows and a static flow regime in the lower half of the river. With high nutrient concentrations, sufficient light availability and shallow water depths, primary production was extremely high in the upper river and greater than respiration (Fig. 4). As mentioned above, high OM loads were delivered to the lower river where the physical character of the river changes dramatically. The switch from coarse to fine substrate from the upper to lower river is the product of sedimentation of OM-rich fine particles out of the water column, leading to elevated sediment oxygen demand (Hogsett and Goel 2013). The combined effect of slow water velocities, increased turbidity, deepening and narrowing of the channel, and the deposition of fine sediment substrate resulted in high respiration rates that overwhelmed rates of primary production in the lower river (Fig. 5). Rates of primary production and reaeration were unable to produce sufficient DO to satisfy the biochemical oxygen demand and remain above the defined threshold concentration (4.0$4.5 \mathrm{mg} \mathrm{L}^{-1}$ depending on the time of year) for aquatic life.

Organic matter has long been recognized as a pollutant of concern, contributing to the dissolved oxygen impairment in the lower Jordan River (Utah DWQ 2012). Modeled after previous studies in relatively pristine watersheds, an OM budget was constructed for a $35-\mathrm{km}$ segment of the Jordan River to evaluate OM dynamics as they relate to the DO impairment. Following in-line with traditional dogma in stream ecology, the largest portion of OM was found in dissolved form (DOC; Fisher and Likens 1973; Fisher 1977). While significant transport of CPOM was clearly visible in the river at different times of year, the total transport of CPOM was relatively insignificant to the total OM budget. Reaches \#1 and \#3 were found to contribute disproportionally to the overall OM load, thus increasing OM transport and exacerbating water quality problems in the lower river. Both of these reaches receive treated effluent, and discharge from water reclamation facilities should not be discounted in restoration efforts.

While DOC was identified as the largest OM pool within the Jordan River, the processes by which DOC is generated and utilized are not fully understood. DOC concentrations were greatest through the fall months and fairly stable over the rest of the year. However, several storm events that likely delivered concentrated pulses of DOC to the river in spring and summer were not captured by regular sampling. A portion of DOC may be highly labile and readily assimilated, as indicated by losses of DOC in reaches \#2, \#4 and \#6; however, the bulk of riverine DOC is generally considered to be highly refractory and unavailable for immediate uptake (McDowell and Fisher 1976). The majority of DOC delivered to the lower river may not be assimilated and is likely either diverted from the river (into the Surplus Canal) or deposited in the Great Salt Lake (see discussion of C cycling and transport below).

Fine particulate organic matter dynamics were influenced by flows released out of the eutrophic Utah Lake (the source of the Jordan River) and in-stream production. Isotopic analyses indicated FPOM was more similar to autochthonous sources than CPOM or leaf litter. FPOM resembled a mixture of terrestrial and autochthonous sources, with autochthonous sources attributed to FPOM released from Utah Lake, and high rates of primary production in the upper Jordan River. This provides evidence of multiple pathways of FPOM generation in addition to CPOM being broken down chemically and physically to FPOM and further into DOC (Cummins 1974; Wallace et al. 1991). It also supports the findings of Imberger et al. (2014) where FPOM in urban Australian streams had isotope values and C:N ratios similar to that of in-stream primary producers. Nutrient enriched water released from Utah Lake is concentrated in FPOM due to pelagic primary production and wind/common carp-induced 
re-suspension of particulate matter within the lake (Fuhriman et al. 1981). Additionally, shallow water depths in the upper river allow substantial light penetration to the streambed to fuel significant benthic primary production, some of which sloughs off into the water column and further increases FPOM and Chl $a$ concentrations. Flow releases into the Jordan River from Utah Lake were shut off during winter months and subsequently FPOM transport was reduced, leaving flows in the upper river less turbid throughout this period. Lower temperatures and less solar radiation likely decreased rates of primary production within the upper river in winter months. Both FPOM AFDM and Chl $a$ were less concentrated in the lower river year-round due to greater turbidity (more inorganic material in suspension), increased shading, and a lower proportion of Utah Lake water in the river.

Coarse particulate organic matter of allochthonous origin was present in the Jordan River throughout the year. However, there was a high degree of variability in the concentration and character of CPOM through the river reaches of interest. The dominance of filamentous algae in CPOM samples from the uppermost sites may have been due to significant in-stream primary production and a limited riparian corridor in the upper river. The shift from filamentous algae to a dominance of allochthonous CPOM (largely from riparian vegetation) in the lower river appeared to be due to increasing turbidity in the lower river and a more expansive and mature riparian tree corridor. Our estimates indicate that the load of CPOM transported within the river is a relatively small portion of the total OM pool $(\sim 1 \%)$, although CPOM undoubtedly plays a role in OM dynamics and stream metabolism. Coarse particulate organic matter may be an important source of DOM, particularly in the fall months due to leaching during the first few days after allochthonous CPOM enters the stream (Meyer et al. 1998). A large portion of this allochthonous DOM may enter the Jordan River from storm drains that entrain the majority of the CPOM. The input of riparian tree leaves to the river in fall months coincided with the highest measured concentrations of DOC during this study. Additionally CPOM may be physically broken down and converted to FPOM and DOM over time (Chapra 1997); however, these pathways do not appear to be dominant due to the relatively small flux of leaf litter in comparison to the high estimates of DOC and FPOM transport, and differences in isotopic signatures between CPOM and FPOM.

When transported to the lower river, OM loads stimulate respiration and result in low dissolved oxygen concentrations. This research demonstrates that the increased OM transport was concentrated in two reaches within the upper river: reaches \#1 and \#3. In the upper river primary production was greater than respiration, and increases in OM transport were associated with tributary inputs, largely consisting of outflow from two water reclamation facilities that discharge into reaches \#1 and \#3 (Fig. 6). Given the estimated spiraling lengths for organic carbon (73-169 km), these inputs are likely delivered in-part to the lower river where they accumulate (through uptake and sedimentation), thus contributing to the dissolved oxygen deficit. In contrast, the lower river reaches were heterotrophic, despite no major increase in OM transport (Fig. 6). Given the presence of high OM loads, the elevated concentrations of nutrients in the water column may increase the rate at which OM is processed and broken down within the river (Benstead et al. 2009). However, low mineralization velocities indicate there is an overabundance of $\mathrm{OM}$ within the river and therefore supply exceeds demand. Additionally, increased nutrient inputs into the river may cause increased fine benthic organic matter export out of the system due to mobilization of detrital carbon (Benstead et al. 2009), which follows in line with the high OM transport estimates but proportionally low standing stock estimates in the Jordan River. 
When spiraling metrics from this study were compared to published data from other river ecosystems, Jordan River carbon mineralization velocities fell within the low to moderate range (0.14-0.44 $\mathrm{m} \mathrm{d}^{-1}$, median 0.26$)$, as they were greater than numerous small midwestern agricultural streams $\left(0.07-0.35\right.$, median $0.16 \mathrm{~m} \mathrm{~d}^{-1}$; Griffiths et al. 2012) and some North American reference streams (0.07-0.54, median $0.10 \mathrm{~m} \mathrm{~d}^{-1}$; Webster and Meyer 1997), similar to large western and midwestern rivers (0.06-0.80, median 0.35); Hall et al. 2015), and lower than numerous sites in the lower Snake River, ID (0.20-2.63, median $0.79 \mathrm{~m} \mathrm{~d}^{-1}$; Thomas et al. 2005) and the Taieri River in New Zealand (0.28-1.09, median $0.70 \mathrm{~m} \mathrm{~d}^{-1}$; Young and Huryn 1997; Fig. 9). A larger "pelagic" zone within large rivers may result in faster mineralization within the water column. Similarly, estimated spiraling lengths (73-169 km, median $107 \mathrm{~km}$ ) were greater than small Midwestern agricultural streams (3-25, median $7 \mathrm{~km}$; Griffiths et al. 2012), the Taieri River (9-84, median 25 km; Young and Huryn 1997) and numerous reference streams (3-53, median $12 \mathrm{~km}$; Webster and Meyer 1997), yet lower than most large western and Midwestern rivers (44-750, median $130 \mathrm{~km}$; Hall et al. 2015).

In addition to physical factors (i.e., slope, depth, canopy cover, etc.) controlling stream metabolism, a river's trophic state may help explain the rate at which OM is assimilated and mineralized. The trophic state of a water body gives an indication of the resources available to the food web and defines the foundation for biological community integrity and ecosystem function (Dodds 2007). Previously mentioned study systems were identified as either oligotrophic or eutrophic and compared mineralization velocity and spiraling length across different systems. Eutrophic rivers such as the Jordan River seem to be associated with slower mineralization velocities and longer spiraling lengths, while oligotrophic systems had faster mineralization velocities and shorter spiraling lengths (Fig. 9). The overabundance of nutrients
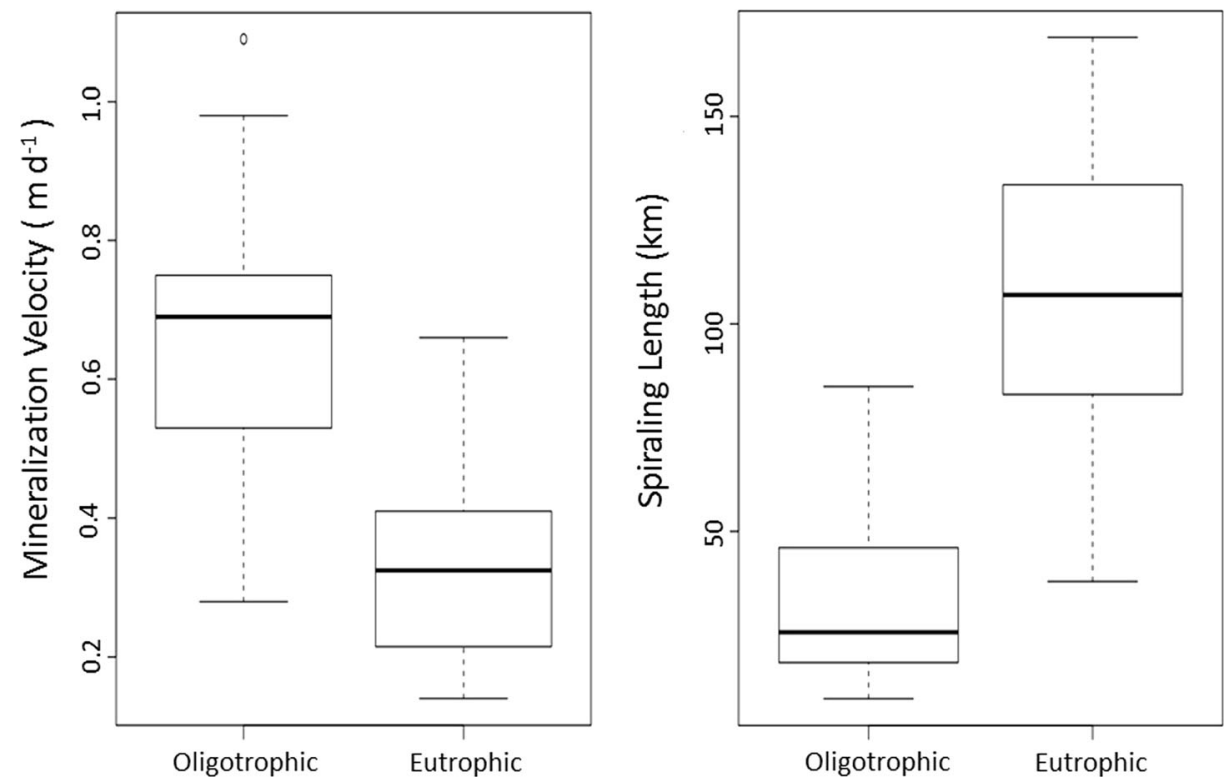

Fig. 9 Estimated carbon mineralization velocities $\left(\mathrm{m} \mathrm{d}^{-1}\right)$ and spiraling lengths $(\mathrm{km})$ for a group of oligotrophic and eutrophic streams. Oligotrophic sites were mainly from the Taeiri River in New Zealand (Young and Huryn 1997) in addition to the Fort River, MA (Webster and Meyer 1997). Eutrophic sites were 2 Midwestern large rivers (Hall et al. 2015) in addition to Jordan River sites. Uptake velocity and spiraling lengths were estimated using equations described in Hall et al. (2015) 
and organic matter within eutrophic systems may overwhelm biological uptake while organisms within oligotrophic streams are more efficient at utilizing and recycling available OM.

The supply of OM and the ability of stream ecosystems to process OM may differ dramatically between streams and even stream reaches. The stream metabolism index (SMI; proposed by Fisher 1977) compares the respiration measured in a given stream reach to the theoretical respiration required to process OM laterally entering into or produced within that reach. For the three furthest upstream reaches in this study, SMI ranged from 0.16-0.38, indicating that loading was much greater than respiration. However, SMI estimates in the lower river ranged from 1.0-1.1 as there was a net reduction in OM transport within two of the three lower river reaches. These SMI results were consistent with the results of the OM budget, which depicted OM loading into the lower river from upper river sites and not from internal production or lateral movement within lower river reaches. Webster and Meyer (1997) reported SMI values greater than 1 for only three of 27 streams and reported a mean of 0.5. Fisher (1977) reported an SMI of 1 in Bear Brook, NH and 0.64 in Fort River, MA; stating that the loading rate is controlled biologically in Bear Brook. SMI values in the lower Jordan River reaches were $>1$ where production was minimal and conditions highly heterotrophic. The OM budget for lower river reaches indicated consumption of $\mathrm{OM}$ and very little lateral movement into the reaches. While abundant OM fuels high rates of respiration within the lower river, the majority of OM in transport may not be consumed within the reach. Heterotrophic streams such as the lower Jordan River may be important sources of $\mathrm{CO}_{2}$ to the environment (Hotchkiss et al. 2015), processing and out-gassing terrestrially fixed carbon to the atmosphere. While progress has been made in including freshwater ecosystems in larger C budgets, significant data gaps still exist, particularly in urban settings (but see Smith and Kaushal 2015).

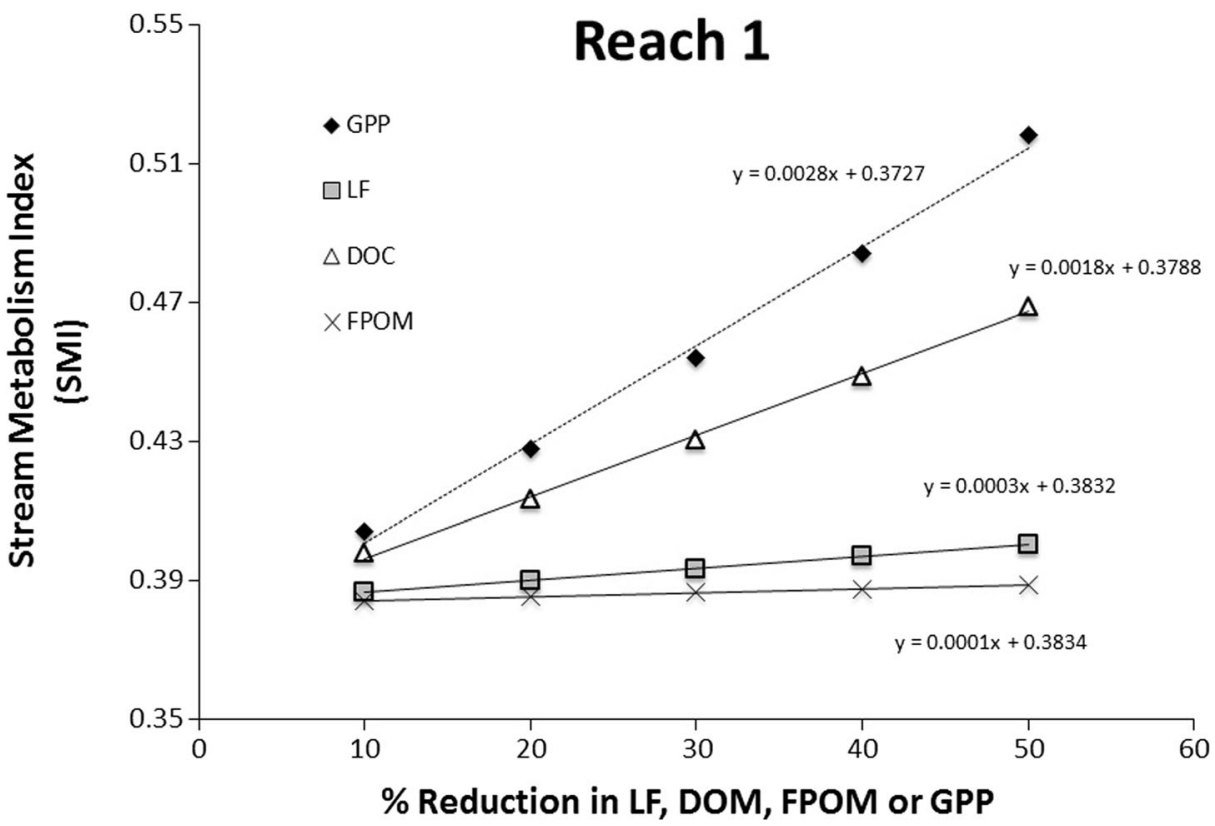

Fig. 10 Estimated stream metabolism index (values) for reach \#1 based on theoretical reductions in litterfall (LF), dissolved organic material (DOM), fine particulate organic matter (FPOM) or gross primary production (GPP). Individual SMI estimates were based on each input parameter changing in isolation 


\section{Conclusion}

Even though the water quality of the Jordan River is severely degraded, steps can be taken to improve water quality and alleviate some of the impacts to the greater stream ecosystem. The identification of OM-gaining reaches helped to isolate areas within the watershed that should be targeted for the reduction of OM loading in the river. This OM budget indicates that tributary inputs in reaches \#1 and \#3 should be investigated as point sources of dissolved organic pollution to the river. While the DO impairment is in the lower river; the SMI analysis indicated that reductions in OM inputs would need to come from upstream of the impaired reach, as lateral movement was minimal in the lower river. Theoretically, a reduction in DOC inputs and/or GPP would move SMI estimates in the upper river closer to 1 (Fig. 10) and reduce the OM load exported to the lower river. Given that SMI estimates are $>1$ for reaches 4 and 6, reductions in GPP and DOC would only increase SMI. A reduction in respiration due to a reduction in OM inputs from the upper river would help to move SMI estimates down towards 1, which would require an overall decrease in the OM load through the river.

Reducing excessive inputs will require authoritative action from state water quality managers. While a reduction in OM inputs is essential, subsequent improvements in water quality may not occur without modifications to the physical character of the lower river. A controlled hydrograph and a constrained and channelized stream channel have resulted in low water velocities, reduced turbulent flow, and increased sedimentation in the lower river. A reduction in sedimentation and increased reaeration and scour would help to alleviate the dissolved oxygen impairment in the lower river. Other possible restoration strategies such as increasing riparian cover in the upper river to decrease primary production, or increasing reaeration in the lower river may also be beneficial, if coupled with a reduction in OM inputs.

Understanding the ecology of urban streams is increasingly important as more watersheds are impacted by human activities. As managers have begun to accept that the majority of urban streams suffer from symptoms of the urban stream syndrome, an improved understanding of the relationships between these symptoms and stream function is necessary. This work serves as an example study for other urban systems and proves that despite alterations to watershed processes, a certain degree of natural function may remain intact in urban streams.

Acknowledgments This research was supported in part by contracts from the South Valley Water Reclamation Facility and the Utah Division of Environmental Quality. MAB and JEK received additional support from NSF EPSCoR cooperative agreement OIA-1208732 awarded to Utah State University, as part of the State of Utah EPSCoR Research Infrastructure Improvement Award. Any opinions, findings, and conclusions or recommendations expressed are those of the authors and do not necessarily reflect the views of the National Science Foundation, State of Utah, or South Valley Water Reclamation Facility. Joe Crawford and Beth Ogata helped in the field, Lisa Ward and Hayden Campbell performed laboratory analyses. Bob Hall provided initial metabolism code in R, and Jason Bahr and Andrew Hobson helped with analyses in R.

Open Access This article is distributed under the terms of the Creative Commons Attribution 4.0 International License (http://creativecommons.org/licenses/by/4.0/), which permits unrestricted use, distribution, and reproduction in any medium, provided you give appropriate credit to the original author(s) and the source, provide a link to the Creative Commons license, and indicate if changes were made.

\section{References}

Abramoff MD, Magalhaes PJ, Ram SJ (2004) Image processing with ImageJ. Biophoton Int 11:36-43 
Arar EJ, Collins GB (1997) Method 445.0 In Vitro Determination of Chlorophyll a and Pheophytin in Marine and Freshwater Algae by Fluorescence. United States Environmental Protection Agency, Office of Research and Development, National Exposure Research Laboratory, Ohio

Benstead JP, Rosemond AD, Cross WF, et al. (2009) Nutrient enrichment alters storage and fluxes of detritus in a headwater stream ecosystem. Ecology 90:2556-2566

Bowden WB, Glime JM, Riis T (2006) Macrophytes and bryophytes. In: Hauer FR, Lamberti GA (eds) Methods in Stream Ecology. Academic Press, San Diego, pp. 381-410

Buchanan TJ, and Somers, WP (1976) Discharge measurements at gauging stations. Book 3, Chapter 3 A. U.S. Geological Survey, Washington, DC

Chapra SC (1997) Surface Water-quality modeling. McGraw-Hill Book Co.

Cummins KW (1974) Structure and function of stream ecosystems. Bioscience 24:631-641. doi:10.2307/1296676

Cummins KW, Sedell JR, Swanson FJ, Minshall GW, Fisher SG, Cushing SE, Petersen RC, and RL Vannote (1983) Organic matter budgets for stream ecosystems: problems in their evaulation. In: Stream Ecology. Springer US, pp 299-353

Dodds WK (2007) Trophic state, eutrophication and nutrient criteria in streams. Trends Ecol Evol 22:669-676

Fisher S (1977) Organic matter processing by a stream-segment ecosystem: Fort River, Massachusetts, USA. Int Rev Gesamten Hydrobiol 62:701-727

Fisher SG, Likens GE (1973) Stream ecosystem: organic energy budget. Bioscience 22:33-35. doi:10.2307/ 1296183

Fry B (2006) Stable isotope ecology. Springer, New York

Fuhriman DK, Merrit LB, Miller AW, Stock HS (1981) Hydrology and Water quality of Utah Lake. Great Basin Naturalist Memoirs 5:43-67

Griffiths N, Tank J, Royer T (2012) Temporal variation in organic carbon spiraling in Midwestern agricultural streams. Biogeochemistry 108:149-169. doi:10.1007/s10533-011-9585-Z

Hall RO, Beaulieu JJ (2013) Estimating autotrophic respiration in streams using daily metabolism data. Freshwater Science 32:507-516. doi:10.1899/12-147.1

Hall RO Jr, Tank JL, Baker MA (2015) Metabolism, gas exchange, and carbon spiraling in rivers. Ecosystems. doi:10.1007/s10021-015-9918-1

Harris D, Horwath WR, van Kessel C (2001) Acid fumigation of soils to remove carbonates prior to total organic carbon or carbon-13 isotopic analysis. Soil Sci Soc Am J 65:1853-1856

Hogsett M, Goel R (2013) Dissolved oxygen dynamics at the sediment-water column interface in an urbanized stream. Environ Eng Sci 30:594-605

Holtgrieve GW, Schindler DE, Branch TA, A'mar T (2010) Simulatneous quantification of aquatic ecosystem metabolism and reaeration using a Bayesian statistical model of oxygen dynamics. Limnol Oceanogr 55: 1047-1063. doi:10.4319/lo.2010.55.3.1047

Hotchkiss ER, Hall RO Jr, Laudon H, Karlsson J (2015) Metabolism, gas exchange, and carbon spiraling in rivers. Nat Geosci. doi:10.1038/NGEO2507

Imberger SJ, Cook PLM, Grace MR, Thompson RM (2014) Tracing carbon sources in small urbanising streams: catchment-scale stormwater drainage overwhelms the effects of reach-scale riparian vegetation. Freshw Biol 59:168-186. doi:10.1111/fwb.12256

Izagirre O, Agirre U, Bermjo M, Pozo J, Elosegi A (2008) Environmental controls of whole-stream metabolism identified from continuous monitoring of Basque streams. J N Am Benthol Soc 27:252-268

Kaushal SS, Belt KT (2012) The urban watershed continuum: evolving spatial and temporal dimensions. Urban Ecosystems 15:409-435

Kelso JE, Baker MA (2015) Filtering with a drill pump: An efficient method to collect suspended sediment. J Am Water Resour Assoc:262-268. doi:10.1111/1752-1688.12368

Lean DRS, Fricker H-J, Charlton MN (1987) The Lake Ontario life support system. Can J Fish Aquat Sci 44: 2230-2240. doi:10.1139/f87-274

McDowell WH, Fisher SG (1976) Autumnal processing of dissolved organic matter in a small Woodland stream ecosystem. Ecology 57:561-569. doi:10.2307/1936440

Meyer JL, Wallace JB, Eggert SL (1998) Leaf litter as a source of dissolved organic carbon in streams. Ecosystems 1:240-249

Newbold JD, Mulholland PJ, Elwood JW, O’Neill RV (1982) Organic carbon Spiralling in stream ecosystems. Oikos 38:266. doi:10.2307/3544663

Odum EP (1968) Energy flow in ecosystems: a historical review. Am Zool 8:11-18

Parnell AC, Inger R, Bearhop S, Jackson AL (2010) Source partitioning using stable isotopes: coping with too much variation. PLoS One 5:1-5. doi:10.1371/journal.pone.0009672

Paul MJ, Meyer JL (2001) Streams in the urban landscape. Annu Rev Ecol Syst 32:333-365

R Core Team (2016) R: a language and environment for statistical computing. R Foundation for Statistical Computing, Vienna, Austria. https://www.Rproject.org/ 
Smith VH, Tilman GD, Nekola JC (1999) Eutrophication: impacts of excess nutrient inputs on freshwater, marine, and terrestrial ecosystems. Environ Pollut 100:179-196. doi:10.1016/S0269-7491(99)00091-3

Stanley EH, Powers SM, Lottig NR (2012) Contemporary changes in dissolved organic carbon (DOC) in humandominated rivers: is there a role for DOC management? Freshw Biol 57:26-42. doi:10.1111/j.1365-2427. 2011.02613.x

Smith RM, Kaushal,SS (2015) Carbon cycle of an urban watershed: exports, sources, and metabolism. Biogeochemistry 126(1-2):173-195

Tank JL, Rosi-Marshall EJ, Griffiths NA (2010) A review of allochthonous organic matter dynamics and metabolism in streams. J N Am Benthol Soc 29:118-146. doi:10.1899/08-170.1

Thomas SA, Royer TV, Snyder EB, Davis JC (2005) Organic carbon spiraling in an Idaho river. Aquat Sci 67: 424 433. doi:10.1007/s00027-005-0790-5

U.S. Climate Data, Your Climate Data (2015) Web. 25 February (2015) http://www.usclimatedata.com/climate/ salt-lake-city/utah/united-states/usut0225

United State Census Bureau, State and County QuickFacts, (2015) Web. 25 February 2015. http://quickfacts. census.gov/qfd/states/49/49049.html

Utah Division of Water Quality (UT DWQ) (2012) Jordan River Total maximum daily load Water quality study phase 1. Prepared by Cirrus Ecological Solutions and Stantec Consulting.http://www.waterquality.utah.gov/ TMDL/JORDAN/JordanRiverTMDL_Approved\%20Document\%20for\%20EPA\%209.26.2012.pdf

Van de Bogert M, Carpenter SR, Cole JJ, Pace ML (2007) Assessing pelagic and benthic metabolism using free water measurements. Limnol Oceanogr Methods 5:145-155

Vannote RL, Minshall GW, Cummins KW (1980) The River continuum concept. Can J Fish Aquat Sci 37:130137. doi:10.1139/f80-017

Venkiteswaran JJ, Schiff SL, Wassenaar L (2008) Aquatic metabolism and ecosystem health assessment using dissolved $\mathrm{O}_{2}$ stable isotope diel curves. Ecol Appl 18:965-982

Wallace JB, Cuffney TF, Webster JR (1991) Export of fine organic particles from headwater streams: effects of season, extreme discharges, and intvertebrate manipulation. Limnol Oceanogr 36:670-682

Wallace JB, Hutchens JJ, Grunbaugh J (2006) Transport and storage of FPOM. In: Methods in stream ecology. Academic Press Inc., San Diego, pp 249-271

Walsh CJ, Roy AH, Feminella JW (2005) The urban stream syndrome: current knowledge and the search for a cure. J N Am Benthol Soc 24:706-723. doi:10.1899/04-028.1

Webster JR, Meyer JL (1997) Stream organic matter budgets. J N Am Benthol Soc 16:3-161

Wenger SJ, Roy AH, Jackson CR, Bernhardt ES, Carter TL, Filoso S, Gibson CA, Hession WC, Kaushal SS, Marti E, Meyer JL, Palmer MA, Paul MJ, Purcell AH, Ramirez A, Rosemond AD, Schofield KA, Sudduth EB, Walsh CJ (2009) Twenty-six key research questions in urban stream ecology: an assessment of the state of the science. J N Am Benthol Soc 28:1080-1098. doi:10.1899/08-186.1

Wetzel RG (2001) Limnology, 3rd edn. Academic Press Inc.

Young R, Huryn A (1997) Longitudinal patterns of organic matter transport and turnover along a New Zealand grassland river. Freshw Biol 38:93-107 